\title{
DOES TAILORED NUTRITIONAL GUIDANCE ENCOURAGE OLDER CAREGIVERS TO INCREASE THEIR PROTEIN INTAKE? THE CARENUTRITION TRIAL (RCT)
}

\author{
S. Kunvik ${ }^{1,2}$, R. Valve ${ }^{2}$, M. Salonoja ${ }^{1}$, M.H. Suominen ${ }^{3}$
}

\begin{abstract}
Background: Older caregivers, males especially, are vulnerable to nutritional problems. Low intake of protein is common and can affect their nutrition and health. Objectives: The aim in this RCT was to investigate the effect of tailored nutritional guidance on protein intake among caregivers aged $\geq 65$ years with protein intake under recommendations $(\leq 1.2 \mathrm{~g} / \mathrm{kgBW} / \mathrm{d})$. Subgroup analysis were made with male caregivers. Design: Data from the CareNutrition randomized controlled trial (RCT). Setting: Community-dwelling caregivers from the Western part of Finland. Participants: Total of 55 caregivers $(\mathrm{n}=28$ intervention group (IG), $\mathrm{n}=27$ control group (CG)) with protein intake of under $1.2 \mathrm{~g} / \mathrm{kgBW} / \mathrm{d}$ at baseline. $45.5 \%$ were male ( $\mathrm{n}=12 \mathrm{male}$ intervention group (MIG), $\mathrm{n}=13$ male control group (MCG)). Intervention: During the six-month intervention tailored nutritional guidance was given to the intervention group during home visit (once) and in group meetings (2-4 times), complemented with written material. Written material was offered to control group. Measurements: Protein intake was assessed with three-day food diary at baseline and final measurements. Main outcome measure was change in protein intake $(\mathrm{g} / \mathrm{kg}$ bodyweight $(\mathrm{BW}) / \mathrm{d})$, analysed among participants with protein intake under $1.2 \mathrm{~g} / \mathrm{kgBW} / \mathrm{d}$ at baseline. Participant characteristics were evaluated with validated methods. Results: Mean protein intake was $0.86 \mathrm{~g} / \mathrm{kgBW} / \mathrm{d}$ in IG and $0.85 \mathrm{~g} / \mathrm{kgBW} / \mathrm{d}$ in CG and among males, $0.89 \mathrm{~g} /$ $\mathrm{kgBW} / \mathrm{d}$ in MIG and $0.79 \mathrm{~g} / \mathrm{kgBW} / \mathrm{d}$ in MCG. There was no significant difference in the change in protein intake between IG and CG. Protein intake increased among MIG by $0.11 \mathrm{~g} / \mathrm{kgBW} / \mathrm{d}$ and decreased in MCG group by $-0.07 \mathrm{~g} / \mathrm{kgBW} / \mathrm{d}, \mathrm{p}=0.007$. There was also a significant increase in protein intake within the IG $(+0.10 \mathrm{~g} / \mathrm{kgBW} / \mathrm{d}, \mathrm{p}=0.038)$. Conclusions: Tailored nutritional guidance resulted in improved protein intake among older male caregivers. Group-based nutritional guidance may boost nutrition among older caregivers, especially males.
\end{abstract}

Key words: Caregivers, elderly, protein intake, nutritional guidance .

\section{Introduction}

Older caregivers are at an increased risk for nutritional problems, such as decreased nutritional status and poor nutrient intake (1-3). Heavy burden, depression, health problems and changes in appetite and food preferences may result in malnutrition (4-8). A low intake of protein is common and can affect caregivers 'nutrition and health $(1,2)$.

Protein is a key nutrient in maintaining muscle health in older people (9). Progressive loss of muscle mass can lead to muscle weakness and physical limitations (10). Given the particularly important role of physical performance in caregiving, carers need sufficient protein in their diets. The consumption of protein-rich foods may decrease with advancing age and reduced food intake

1. The Social Services and Healthcare Centre of Pori, Finland; 2. Department of Food and Nutrition, University of Helsinki, Finland; 3. Unit of Primary Health Care, Helsinki University Central Hospital, Finland.

Corresponding Author: S. Kunvik, The Social Services and Healthcare Centre of Pori, Finland, susanna.kunvik@gmail.com
(11). Hence, there is a need to find ways of encouraging older people to increase their protein intake in their daily diets (12).

Even though caregivers are prone to nutritional problems, only few interventions have targeted this group of individuals (13), and nutrition education has only occasionally been a component of caregiver education and support programmes (14). Nutritional guidance could be effective in improving well-being and health (14), as well as nutrient intake (15). Male caregivers have been identified as a special group needing guidance. Weak cooking skills and lack of nutritional knowledge have been associated with a poor dietary quality among older males $(16,17)$. Being male is also known to be associated with poor nutrient intake and increased concern about nutrition among caregivers $(18,19)$.

The purpose of this article was to assess the effectiveness of tailored nutritional guidance on nutrient intake, especially of proteins, among caregivers aged $\geq 65$ years with protein intake under recommendations $(\leq 1.2 \mathrm{~g} / \mathrm{kgBW} / \mathrm{d})$. Special attention was given to male caregivers based on subgroup analysis. 


\section{Methods}

In this article we used the data of CareNutrition randomized controlled intervention trial, which explores the effectiveness of tailored nutritional counselling on protein intake among older caregivers $(\geq 65)$ with normal cognition. The six-month intervention included tailored nutritional guidance during home visits and in group meetings, complemented with written material. The main outcome measure was the change in protein intake $(\mathrm{g} /$ $\mathrm{kgBW} / \mathrm{d}$ ). Our focus in this article is on participants with a protein intake of under $1.2 \mathrm{~g} / \mathrm{kgBW} / \mathrm{d}$ (nutrition recommendation in Finland and intervention target) at baseline according to three-day food diaries. Special concerns arose among male caregivers based on subgroup analysis.

The participants were recruited following the health screening of caregivers. The recruitment procedure and inclusion criteria in CareNutrition trial are described in Figure 1, and in a previous article (2). The inclusion criteria were: age of $\geq 65$, officially confirmed caregiver status, living at home, and normal cognition (MMSE points $\geq 25$ geriatric assessment). The study was approved by the Ethics Committee of the Hospital District of Southwest Finland. Informed consent was obtained from each participant. The trial was described and registered at Australian New Zealand Clinical Trials Registry, Trial Id: ACTRN12615001254583.

Figure 1

Study flow chart

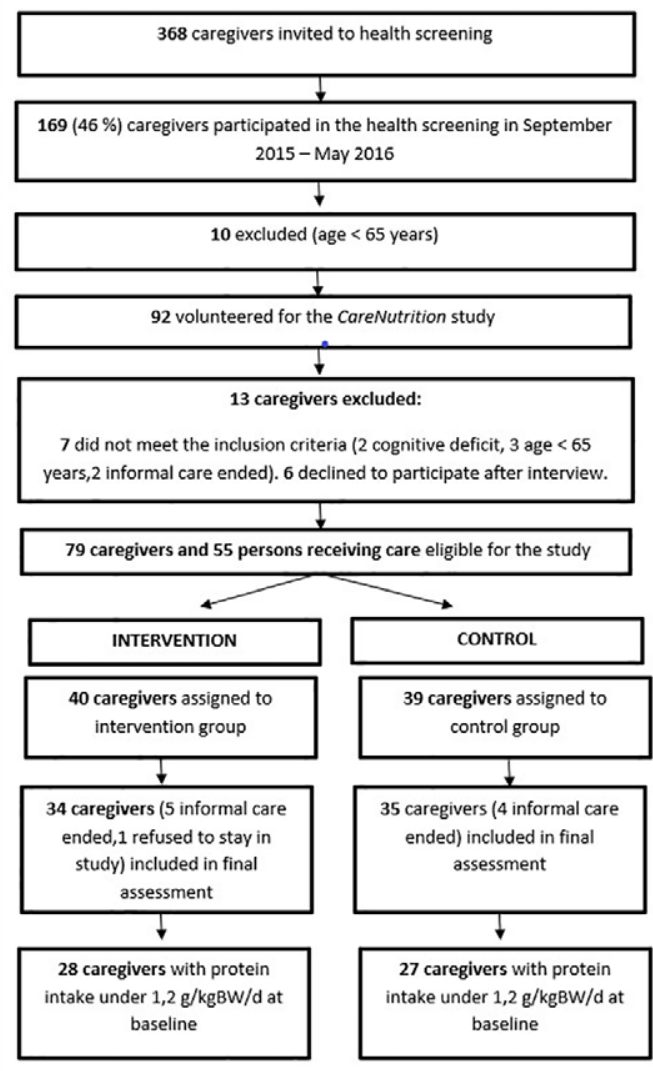

\section{Measurements}

Baseline measurements were taken during two different appointments: the nurse's health screening and the nutritionist's home visit. The following measures were used: the MMSE (20) for cognition; the Katz index (21) for activities of daily living (ADL); the Lawton-Brody questionnaire (22) for instrumental activities of daily living (IADL); the 15D instrument (23) for health-related quality of life (HRQol); the Geriatric Depression Scale (GDS-15) (24) for depression; and an open question for information on medication. An experienced geriatrician reviewed the health-screening papers and recommended examinations if needed. Following the appointment with the nurse, a nutritionist made a home visit to screen nutritional status in line with the MNA (25). Nutrient intake was measured via three-day food diaries at baseline and at final measurements. The Finnish National Food Composition Database was used to analyse food intake. Check calls were made to confirm the amounts and types of food being consumed and to assess possible underreporting. Ideal bodyweight was used to calculate protein intake $\mathrm{g} / \mathrm{kgBW} / \mathrm{d}$ : if body mass index (BMI) was $20-30 \mathrm{~kg} / \mathrm{m} 2$ we used the actual BMI, if under 20 $\mathrm{kg} / \mathrm{m} 2$ we adjusted it to 20 , and if above $30 \mathrm{~kg} / \mathrm{m} 2$ we adjusted it to 30 . Post-intervention feedback was gathered from intervention group by means of a structured questionnaire by mail.

\section{Randomization}

After baseline measurements and inclusion, the caregivers were randomly allocated one by one to the intervention (IG) or the control group (CG) according to a computer-generated, blocked randomization list. The person who carried out the randomization was unrelated to the investigation and unfamiliar with the procedure. From this sample, subgroup analysis was made with male intervention group (MIG) and male control group (MCG).

\section{Intervention}

The intervention continued for six months. During this period members of the intervention group were given tailored nutritional guidance in their homes on one occasion (1 - 2 hours), and they had the opportunity to attend between two and four group meetings (Table 1). The key person in the intervention, who gave tailored nutritional guidance at the caregiver's home and arranged the group meetings, was a trained nutritionist.

The nutritionist visited the caregivers' homes at the beginning of the intervention. Nutritional guidance was based on the participant's nutritional status, nutrient intake and background information, and on discussion with the nutritionist. An ideal level of protein intake was then calculated for each participant, who was given a 
Table 1

Overview of the tailored nutritional intervention and the procedures followed in the control group

\begin{tabular}{|c|c|c|}
\hline Main elements & $\begin{array}{l}\text { Nutritional intervention in the intervention } \\
\text { group }\end{array}$ & Control-group procedures \\
\hline Tailored nutritional guidance at home & $\begin{array}{l}\text { A 1-2-hour home visit at the beginning of } \\
\text { the six-month intervention. Nutritional } \\
\text { guidance based on food diaries ( } 3 \text { days), } \\
\text { measurements and discussions. }\end{array}$ & After completion of the trial \\
\hline Nutrition care plan & $\begin{array}{l}\text { Targeted especially on health promotion. } \\
\text { Included feedback on each caregiver's meal } \\
\text { rhythm and intake of energy, protein, fibre } \\
\text { and some vitamins. After the discussion } \\
\text { dietary targets were agreed and written in } \\
\text { the care plan. }\end{array}$ & After completion of the trial \\
\hline Booklets & $\begin{array}{l}\text { Different booklets were handed out based } \\
\text { on the guidance: general information about } \\
\text { nutrition, good protein sources, hydration } \\
\text { and special diets if needed. }\end{array}$ & $\begin{array}{l}\text { A booklet on nutrition was } \\
\text { sent upon allocation to the } \\
\text { control group }\end{array}$ \\
\hline Group meetings & $\begin{array}{l}\text { Caregivers had a choice of group meetings } \\
\text { during the intervention: cooking classes ( } 2 \\
\text { times) or group discussion ( } 4 \text { times) }\end{array}$ & None \\
\hline Telephone contact & $\begin{array}{l}\text { Food records were checked at the beginning } \\
\text { of the intervention and a follow-up call was } \\
\text { made after } 3 \text { months. A feedback call was } \\
\text { made after intervention. }\end{array}$ & Food records were checked \\
\hline
\end{tabular}

written nutritional care plan and other material.

The nutritional care plan and guidance highlighted the positive factors in the participants' diets, such as adequate energy intake and the use of good protein sources (e.g. quality, quantity, distribution during the day). The nutritionist and the caregiver discussed appropriate nutritional aims, which were included in the care plan. The main aims usually related to finding easy and practical ways of increasing protein intake. The participants were given booklets about healthy nutrition.

Each caregiver had the opportunity to attend between group discussions (held 4 times) and cooking courses (held 2 times) during the six-month period. The aim of the discussions was to provide peer support and to reinforce the nutritional message. The nutritionist guided the conversations as the caregivers discussed their situations at home, with a view to focusing on cooking and nutrition. Each discussion lasted for 1.5 - 2 hours. The cooking sessions ( 2.5 hours) focused on protein-rich and traditional foods. Each session included a short 15-minute discussion about healthy nutrition. Dishes were prepared and enjoyed together.

Members of the control group received normal community care if necessary and were given a booklet about healthy nutrition. Nutritional guidance in the form of a home visit and a nutrition care plan was offered after the final measurements.

\section{Statistical analyses}

CareNutrition trial sample size was calculated based on the participants expected change in protein intake. With a standard deviation (SD) of 0.3 (1) and type-1 error of $5 \%$ and at a power of $80 \%$ per cent and an expected change in protein intake from $1 \mathrm{~g} / \mathrm{kgBW} / \mathrm{d}$ (1) to $1.2 \mathrm{~g} /$ $\mathrm{kgBW} / \mathrm{d}$ in the intervention group, and with no change in the control group, each group would require 51 persons (accounting for drop-out) to show statistical significance. From this sample we analysed participants with protein intake under $1.2 \mathrm{~g} / \mathrm{kgBW} / \mathrm{d}$ at baseline in this article. Subgroup analyses were made with male caregivers.

The results are presented as means with SDs or as percentages, with $95 \%$ confidence intervals for the major outcomes. Statistical differences between the groups (IG vs. CG and MIG vs. MCG) were determined by t-tests, Mann Whitney U-test, Chi Square test or Fisher's exact test. The main outcome measures were subjected to an analysis of covariance (ANCOVA): age, gender, BMI and value at baseline were added to model as covariates. In the case of violation of the assumptions (e.g. nonnormality), a bootstrap-type test was used. SPSS version 22.0 (SPSS, Inc., Chicago, IL) and STATA 14.1 were used in statistical analyses. 


\section{Results}

\section{Baseline characteristics}

A total of 69 caregivers completed the CareNutrition trial (Figure 1) of whom 55 caregivers $(n=28$ IG, $n=27$ CG) had protein intake of under $1.2 \mathrm{~g} / \mathrm{kgBW} / \mathrm{d}$ at baseline (sample in this article). Table 2 gives the baseline characteristics of the IG and CG. The mean age of the participants was 73.5 (SD 6.0) years, and most (81.8\%) were spousal caregivers. $45.5 \%$ were male $(n=12$ MIG, $\mathrm{n}=13 \mathrm{MCG}$ ) with a mean age of 74.4 years (SD 6.4).

Table 2

Baseline characteristics of the caregivers in the IG and CG

\begin{tabular}{|c|c|c|c|}
\hline Characteristic & $\begin{array}{l}\text { Intervention } \\
\quad(n=28)\end{array}$ & $\begin{array}{l}\text { Control } \\
(n=27)\end{array}$ & p-value \\
\hline Age, mean (SD) & $73.9(5.9)$ & $73.1(6.2)$ & 0.634 \\
\hline Male gender $(\%)$ & 42.9 & 48.1 & 0.694 \\
\hline Spousal caregiver $(\%)$ & 85.0 & 77.8 & 0.720 \\
\hline Education years, mean (SD) & $9.6(2.9)$ & $9.7(2.8)$ & 0.956 \\
\hline \multicolumn{4}{|l|}{ MNA categories $(\%)$} \\
\hline Normal nutritional status, $>23.5$ p. & 85.7 & 85.2 & 0.564 \\
\hline Risk of malnutrition, $17-23.5 \mathrm{p}$. & 10.7 & 14.8 & \\
\hline Malnourished, $<17$ p. & 3.6 & 0 & \\
\hline Prepares family food (\%) & 75 & 76.9 & 0.813 \\
\hline BMI kg/m2, mean (SD) & $28.1(3.9)$ & $29.3(4.9)$ & 0.354 \\
\hline MMSE points, mean (SD) & $26.6(2.5)$ & $27.5(2.7)$ & 0.213 \\
\hline \multicolumn{4}{|l|}{ Depression (GDS-15) } \\
\hline Mild or moderate depression $(\%)$ & 7.1 & 3.7 & 0.733 \\
\hline Severe depression $(\%)$ & 3.6 & 0 & \\
\hline Number of medications, mean (SD) & $3.7(3.3)$ & $3.6(3.2)$ & 0.954 \\
\hline ADL points, mean (SD) & $5.9(0.3)$ & $5.9(0.3)$ & 0.646 \\
\hline IADL points, mean (SD) & $7.9(0.3)$ & $7.9(0.3)$ & 1.00 \\
\hline 15D score, mean (SD) & $0.9(0.08)$ & $0.9(0.08)$ & 0.259 \\
\hline
\end{tabular}

Most of the caregivers $(85.5 \%)$ had a good nutritional status (MNA points $>23.5$ ), $12.7 \%$ were at risk of malnutrition (MNA points 17-23.5) and one person (1.8\%) suffered from malnutrition (MNA points $<17$ ). Of all the caregivers, $75.7 \%$ prepared their family meals themselves, but only half $(50 \%)$ of the males did so (difference between females, $p=0.001$ ). Levels of cognition were good (mean MMSE score 27.1, SD 2.6), as was physical functioning according to the ADL and IADL scores. The male caregivers had lower IADL scores than female, indicating weaker instrumental activities of daily living (7.8 (0.4) points vs. 8.0 (SD 0.0) points, $\mathrm{p}=0.003$ ). Most participants were of normal weight (mean BMI 28.7 $\mathrm{kg} / \mathrm{m} 2$, SD 4.4), the mean number of medications was 3.6 (SD 3.2) and HRQoL was good (15D score 0.9, SD
0.08). According to the GDS-15, 5.5\% suffered from mild or moderate depression and one person from severe depression. There were no differences between the groups at baseline (IG vs. CG and MIG vs. MCG).

\section{Protein and energy intake at baseline}

Mean protein intake was 0.86 (SD 0.17) $\mathrm{g} / \mathrm{kgBW} / \mathrm{d}$ in IG and 0.85 (SD 0.17) g/ kgBW/d in CG, $\mathrm{p}=0.73$. Among males, protein intake was 0.89 (SD 0.18) $\mathrm{g} / \mathrm{kgBW} / \mathrm{d}$ in MIG and 0.79 (SD 0.16) g/ kgBW/d in MCG, $\mathrm{p}=0.18$. There were no statistical differences between groups.

The mean energy intake among IG was 1433 (SD 295) $\mathrm{kcal} / \mathrm{d}$ and among CG 1642 (SD 340) $\mathrm{kcal} / \mathrm{d}, \mathrm{p}=0.18$ (Table 3). Among males, energy intake at baseline in the MIG was 1558 (SD 256) kcal/d and among MCG 1800 (SD 296) $\mathrm{kcal} / \mathrm{d}$. MCG had greater energy intake $(\mathrm{p}=0.004)$.

\section{Changes in protein and energy intake after six months}

The mean change in protein intake from baseline to six months was +0.10 (SD 0.2) g/ $\mathrm{kgBW} / \mathrm{d}$ in the IG and +0.04 (SD 0.2) $\mathrm{g} / \mathrm{kgBW} / \mathrm{d}$ in the CG. There were no significant differences between the groups $(p=0.26)$, but there was a significant increase within IG from baseline to the final measurements; from 0.86 (SD 0.17) $\mathrm{g} / \mathrm{kgBW} / \mathrm{d}$ to 0.96 (SD $0.25) \mathrm{g} / \mathrm{kgBW} / \mathrm{d}, \mathrm{p}=0.038$.

There was a significant difference in the change in protein intake between the two groups of male caregivers: it increased in the MIG 0.11 (SD 0.22, CI $-0.01-0.22) \mathrm{g} /$ $\mathrm{kgBW} / \mathrm{d}$ and decreased in the MCG $-0,07$ (SD 0.19, CI $-0.19-0.04) \mathrm{g} / \mathrm{kgBW} / \mathrm{d}(\mathrm{p}=0.007)$. Total intake in the MIG was thus $1.0 \mathrm{~g} / \mathrm{kgBW} / \mathrm{d}$ at the final measurement, compared with $0.72 \mathrm{~g} / \mathrm{kgBW} / \mathrm{d}$ in the MCG.

The mean change in energy intake from baseline to six months was $+102 \mathrm{kcal} / \mathrm{d}$ (SD 254) in the IG and +37 (SD 430) $\mathrm{kcal} / \mathrm{d}$ in the CG, with no statistical difference between groups $(p=0.49)$, (Table 3$)$. Within IG there was a statistical increase in energy intake $(\mathrm{p}=0.043)$. Among males, there was a significant difference in the change in energy intake: an increase of 97 (SD 254) $\mathrm{kcal} / \mathrm{d}$ in the MIG and a decrease of -192 (SD 426) $\mathrm{kcal} / \mathrm{d}$ in the MCG, $(\mathrm{p}=0.05)$.

Related to energy intake, the BMI in the CG decreased from $29.3 \mathrm{~kg} / \mathrm{m} 2$ to $28.8 \mathrm{~kg} / \mathrm{m} 2$ (- 0.5 (SD 1.0) $\mathrm{kg} / \mathrm{m} 2$, $\mathrm{p}=0.014)$. There were no changes in other groups.

\section{Feedback from the intervention}

All intervention group caregivers received nutritional guidance at home once during the intervention. According to feedback $70.4 \%$ of caregivers in the IG though the nutritionist's home visit was useful (males $83.3 \%)$ as well as nutritional guidance $(74.7 \%$, males $83.3 \%$ ). A total of $75 \%$ of the caregivers went to the group 
Table 3

Mean levels of energy and protein intake and changes from baseline to six months in the IG and CG

\begin{tabular}{|c|c|c|c|c|c|c|c|c|}
\hline & \multicolumn{4}{|l|}{ Baseline } & \multicolumn{4}{|l|}{ Change after 6 months } \\
\hline & $\begin{array}{l}\text { Energy intake, } \\
\text { kcal, mean (SD) }\end{array}$ & p-value ${ }^{*}$ & $\begin{array}{l}\text { Protein intake, } \\
\text { g/kgBW/d, mean } \\
\text { (SD) }\end{array}$ & p-value* & $\begin{array}{l}\text { Energy intake, } \\
\text { kcal, mean (SD, CI } \\
95 \% \text { ) }\end{array}$ & p-value ${ }^{*}$ & $\begin{array}{l}\text { Protein intake, } \\
\text { g/kgBW/d, mean (SD, } \\
\text { CI 95\%) }\end{array}$ & p-value* \\
\hline Intervention $(\mathrm{n}=28)$ & $1433(295)$ & 0.18 & $0.86(0.17)$ & 0.73 & $102(254,3-201)$ & 0.49 & $0.10(0.2,0.02-0.17)$ & 0.26 \\
\hline
\end{tabular}

*p-value for statistical test between IG and CG; adjusted for age, gender, BMI and value at baseline

meetings and they were considered useful $(60 \%$, males $66.7 \%$ ). We found no statistical differences between males and females in the feedback.

\section{Discussion}

We found in this study that tailored nutritional guidance seems to encourage increased protein intake in older $(\geq 65)$ caregivers, although there were no statistically significant differences between the intervention and the control group. However, the intervention was effective among male caregivers who received tailored nutritional guidance in that their intake of protein and energy increased during the six-month intervention.

We selected change in protein intake as the main outcome measure based on previous studies indicating a protein intake among older caregivers of less than the recommended level (1). The protein intake at baseline among the caregivers we studied was only $0.85-0.86$ $\mathrm{g} / \mathrm{kg} \mathrm{IBW} / \mathrm{d}$, which is lower than the $1.2-1.4 \mathrm{~g} / \mathrm{kg} / \mathrm{d}$ recommended in Finland (26). The amount of dietary protein tends to decline progressively with advancing age due to reduced energy needs and intake, the loss of appetite and difficulties in acquiring and preparing food, although the caregivers in this study were in quite good physical shape (ADL, IADL). Our intervention target was to increase the protein intake to $\geq 1.2 \mathrm{~g} / \mathrm{kg} \mathrm{BW} / \mathrm{d}$ on the grounds that it may help older caregivers to retain the muscle mass and good physical functioning required for taking care of another person $(12,27-29,36,37)$. We found statistically significantly increased protein intake in the IG, from $0.86 \mathrm{~g} / \mathrm{kgBW} / \mathrm{d}$ to $0.96 \mathrm{~g} / \mathrm{kgBW} / \mathrm{d}$, after the six-month nutritional intervention, but the difference between IG and CG was not significant.

Nutritional intervention was especially effective among male caregivers, whose protein intake increased in MIG from $0.89 \mathrm{~g} / \mathrm{kgWB} / \mathrm{d}$ to $1.0 \mathrm{~g} / \mathrm{kgBW} / \mathrm{d}$ and decreased in MCG from $0.79 \mathrm{~g} / \mathrm{kgBW} / \mathrm{d}$ to $0.72 \mathrm{~g} / \mathrm{kg} /$ $\mathrm{BW} / \mathrm{d}$. There are several factors that could explain why male benefitted more from the nutritional guidance. Only half of these male caregivers prepared their family meals, and hence may need more guidance. Taking on a caregiver`s role changes the situation at home if the person concerned is not familiar with household activities. Cooking and shopping have traditionally been women`s work in this age group (30), hence older males may have weak cooking skills and inadequate nutritional knowledge $(17,30)$ : both factors have been associated with a poor-quality diet $(16,17)$. Male gender is also known to be associated with poor nutrient intake and increased concerns about nutrition in caregivers $(18,19)$. According to the feedback in our study, male caregivers were satisfied with the nutritional intervention. It has been suggested that community-based nutrition and cooking guidance are beneficial educational activities among older male (31). Our results support findings implying that older male caregivers need special support to cope with household activities, and that combining nutritional guidance with practical learning may be an effective way of doing this.

We did not reach the intervention target of $1.2 \mathrm{~g} / \mathrm{kg}$ $\mathrm{BW} / \mathrm{d}$ in protein intake. One reason for this may be that the protein intake of the caregivers at baseline was lower than expected. Also, we were not able to recruit enough participants in each group, which weakens the statistical power of the sample: with sample-size calculations of 102 participants, only 69 caregivers completed CareNutrition trial, of whom 55 had protein intake under $1.2 \mathrm{~g} / \mathrm{kgBW} / \mathrm{d}$ at baseline. Therefore, the sample in this article is quite small. In addition, protein intake also increased slightly in CG, even though not statistically significantly. This may have been because at the beginning of the trial CG also received written nutritional material, which highlighted the importance of proper protein intake. Control-group contamination could also explain the increase in protein intake, in that the trial was conducted in a small city and the participants may have known each other from the caregivers' peer-support groups and events. Adequate protein intake was highlighted in the guidance and this message may have spread. Moreover, the Hawthorne effect, meaning that individuals modify some aspects of their behaviour in response to their awareness of being observed, is typical in intervention studies (32). Nevertheless, there is a notable benefit of an increase in protein intake among the caregivers in this study: a protein intake of $1.0 \mathrm{~g} / \mathrm{kg} \mathrm{BW} / \mathrm{d}$ has several positive 
effects, including protection against weight loss and the maintenance of physical functioning $(12,33,38)$.

The mean increase in protein intake in IG and MIG was $0.1 \mathrm{~g} / \mathrm{kgBW} / \mathrm{d}$, which is in line with results reported earlier in similar interventions conducted among people with Alzheimer`s disease (13). A systematic review and meta-analysis of individualized dietary counselling for nutritionally at-risk older patients reported a mean increase in total protein intake of $10.13 \mathrm{~g} / \mathrm{d}$ (34). The mean increase of $0.1 \mathrm{~g} / \mathrm{kgBW} / \mathrm{d}$ in protein intake in our study means about $7.0-7.7 \mathrm{~g}$ total increase among persons weighing $70 \mathrm{~kg}$, which corresponds to two decilitres of milk or yoghurt, one egg or four slices of meat for example. Our results indicate that the total increase in protein intake following nutritional guidance could be compared to one snack. Effective way of increasing protein intake among older persons is to offer familiar protein-rich foods. Interventions targeted at older people should be achievable and acceptable in the long term and should be easily incorporated into their dietary pattern. It is for this reason that food-based strategies rather than supplemental drinks could be recommended as an initial approach to optimising protein intake (12). The caregivers in our study were advised on how to add familiar protein-rich foods to their daily diets. Nutritional aims were discussed with them, which increased their motivation to make dietary changes.

The six-month intervention also led to an increase in energy intake in the IG and the MIG of 102 and $97 \mathrm{kcal}$, respectively. In addition, the energy intake of those in MCG decreased by almost $200 \mathrm{kcal} / \mathrm{d}$. We observed a decrease in BMI only in the CG, which also indicates sufficient energy intake in the intervention groups. Even though the increase in energy intake is small, it is significant in terms of protein bioavailability: if there is insufficient energy intake, protein is used as an energy source (12). It is also noteworthy that the caregivers in this study did not seem to increase their protein intake at the cost of sufficient energy intake, which could have happened if energy-dense foods had been replaced with protein-rich foods such as dairy products that tend not to contain a lot of energy.

The strength of our study is that it provides important information on protein intake and the effectiveness of tailored nutritional counselling targeted at older caregivers. A few similar studies (13) have been conducted, but to our knowledge this is the first RCT reporting the effects of nutritional guidance on protein intake among older caregivers. Our study was conducted as a randomized controlled trial, which is an efficient method for determining cause-effect relationships. Tailored nutritional guidance facilitated the giving of personal nutritional advice, which is important given the dietary heterogeneity. Nutrient intake was assessed by means of a three-day food diary, which is considered a good way of evaluating nutrition among older people (35).

Nevertheless, our study has some potential limitations.
Because of the specificity of our recruitment and the fact that many caregivers did not have the energy or the interest to participate, the number of informants was small, and the study population was selective. This weakens the generalizability of the findings. Selection bias is also possible because the participants were in quite good physical shape and were keen to be involved. This may indicate that they were more health conscious than the average older population and could affect the efficacy of the intervention. Nutrient intake was assessed from three-day food diaries, which could have affected the results through over- or underreporting. Three days may not be long enough to show actual food intake over a longer period. However, we made check calls to confirm the amounts and types of food being consumed and participants had fairly stable food habits, as older people usually do.

\section{Conclusion}

Our results show that tailored nutritional guidance was effective in terms of enhancing protein and energy intake among older ( $\geq 65 \mathrm{y})$ male caregivers, and thus may be useful for all older caregivers. These findings highlight the importance of and need for preventive nutritional guidance. Further studies are required to obtain more information about nutrient intake among older caregivers, and there is a need for more targeted interventions, especially for male.

Funding: The CareNutrition study received funding from the National Institute for Health and Welfare (THL) in Finland. The funder had no role in the design and conduct of the study; in the collection, analysis, and interpretation of data; in the preparation of the manuscript; or in the review or approval of the manuscript.The authors are independent researchers and are not associated with the funders.

Conflict of interest: Mrs. Kunvik reports grant from Satakunta Hospital District, Finland, during the conduct of this article. Other authors declare that they have no conflicts of interest directly relevant to this report. However, Dr Suominen reports co-operating professionally with Nutricia Medical and Verman.

Ethical standard: This study was conducted according to the guidelines laid down in the declaration of Helsinki and all procedures were approved by the Ethics Committee of the Hospital District of Southwest Finlan. Informed consent was obtained from each participant.

\section{References}

1. Puranen T, Jyvakorpi S, Pitkala K et al. Nutritional intervention of patients with Alzheimer's disease living at home with their spouse: a randomized controlled trial: baseline findings and feasibility. J Aging Res Clin Practice. 2013;2:236-241

2. Kunvik S, Valve R, Salminen $\mathrm{K}$ et al. Baseline findings of CareNutrition intervention (RCT) among older caregivers - risk of malnutrition and insufficient protein intake. Journal of Aging Research \& Clinical Practice. 2017;6.

3. Torres MJ, Dorigny B, Kuhn M et al. Nutritional Status in CommunityDwelling Elderly in France in Urban and Rural Areas. 2014;9:e105137.

4. Schulz R, Martire LM. Family caregiving of persons with dementia: prevalence, health effects, and support strategies. Am J Geriatr Psychiatry 2004;12:240-249.

5. Doran T, Drever F, Whitehead M. Health of young and elderly informal carers. BMJ. 2003;327:1388.

6. Sörensen, S, Pinquart M, \& Duberstein P. How effective are interventions with caregivers? An updated meta-analysis. The gerontologist. 2002;42(3):356372.

7. Aggarwal B, Liao M, Christian A, Mosca L. Influence of caregiving on lifestyle and psychosocial risk factors among family members of patients 
hospitalized with cardiovascular disease. J Gen Intern Med. 2009;24(1):93-8.

8. Alzheimer's Disease International. World Alzheimer Report. The global economic impact of dementia.2010. http: / / www.alz.co.uk/ research/files / WorldAlzheimerReport2010.pdf. (Accessed 6 January 2018).

9. Baum JI, Kim IY, Wolfe RR. Protein Consumption and the Elderly: What Is the Optimal Level of Intake? Nutrients. 2016;8.6:359.

10. Forbes SC, Little JP, Candow DG. Exercise and nutritional interventions for improving aging muscle health.Endocrine. 2012;42.1:29-38.

11. Volpi E, Campbell W, Dwyer JT et al. Is the optimal level of protein intake for older adults greater than the recommended dietary allowance?. Journals of Gerontology Series A: Biomedical Sciences and Medical Sciences. 2012;68(6):677-681.

12. Nowson C \& O'Connell S. Protein requirements and recommendations for older people: a review. Nutrients. 2015;7.8:6874-6899.

13. Suominen MH., Puranen TM, Jyväkorpi S et al. Nutritional guidance improves nutrient intake and quality of life,and may prevent falls in aged persons with Alzheimer disease living with a spouse (NuAD trial). The journal of nutrition, health \& aging. 2015;19.9:901-907.

14. Silver HJ, \& Wellman NS. Nutrition education may reduce burden in family caregivers of older adults. Journal of nutrition education and behavior. 2002;34:S53-S58

15. Baldwin C, \& Weekes CE. Dietary counselling with or without oral nutritional supplements in the management of malnourished patients: a systematic review and meta-analysis of randomised controlled trials. Journal of Human Nutrition and Dietetics. 2012;25.5:411-426.

16. Baker $\mathrm{AH}$, Wardle J. Sex differences in fruit and vegetable intake in older adults. Appetite. 2003;40.3:269-275.

17. Hughes G, Bennett KM \& Hetherington MM. "Old and alone: barriers to healthy eating in older men living on their own". Appetite. 2004;43.3:269-276.

18. Puranen TM, Pietila SE, Pitkala K et al. Caregivers' male gender is associated with poor nutrient intake in AD families (NuAD-trial). J.Nutr.Health Aging. 2014; 18.7:672-676.

19. Fjellstrom C, Starkenberg A, Wesslen A et al. To be a good food provider: an exploratory study among spouses of persons with Alzheimer's disease. American Journal of Alzheimer's Disease and Other Dementias. 2010;25.6:521526.

20. Folstein MF, Folstein SE, McHugh PR. "Mini-mental state". A practical method for grading the cognitive state of patients for the clinician. J Psychiatr Res. 1975;12:189-198.

21. Katz S, Ford AB, Moskowitz RW et al. Studies of Illness in the Aged. the Index of Adl: a Standardized Measure of Biological and Psychosocial Function. JAMA. 1963;185:914-919.

22. Lawton MP, Brody EM. Assessment of older people: self-maintaining and instrumental activities of daily living. Gerontologist. 1969;9:179-186.

23. Sintonen $\mathrm{H}$. The $15 \mathrm{D}$ instrument of health-related quality of life: properties and applications. Ann Med 2001;33:328-336.

24. Yesavage JA, Brink TL, Rose TL et a. Development and validation of geriatric depression screening scale. J Psychiatr Res. 1983;17:37-49.

25. Vellas B, Guigoz Y, Garry PJ et al. The Mini Nutritional Assessment (MNA) and its use in grading the nutritional state of elderly patients. Nutrition. 1999;15:116-122.

26. Finnish Nutrition Recommendations. National Nutrition Council. Health from food - The Finnish Dietary Guidelines.2014.

27. Pedersen AN, Cederholm T. Health effects of protein intake in healthy elderly populations: a systematic literature review. Food Nutr Res. 2014;58.

28. Lancha AH,Jr, Zanella R,Jr, Tanabe SG et al.Dietary protein supplementation in the elderly for limiting muscle mass loss. Amino Acids. 2017;49:33-47.

29. Genaro Pde S, Pinheiro Mde M, Szejnfeld VL, Martini LA. Dietary protein intake in elderly women: association with muscle and bone mass. Nutr Clin Pract. 2015;30.2:283-289.

30. Roos G, Prattala R \& Koski K. Men, masculinity and food: interviews with Finnish carpenters and engineers. Appetite. 2001;37.1:47-56.

31. Keller HH, Gibbs A, Wong S et al. Men can cook! Development, implementation, and evaluation of a senior men's cooking group. J Nutr Elder. 2004;24.1:71-87.

32. Koh ET \& Owen WL. Introduction to nutrition and health research. Springer Science \& Business Media. 2012.

33. Gray-Donald K, Arnaud-McKenzie DS, Gaudreau et al. Protein Intake Protects against Weight Loss in Healthy Community-Dwelling Older Adults, 2. The Journal of nutrition. 2013;144.3:321-326.

34. Munk T, Tolstrup U, Beck AM et al. Individualised dietary counselling for nutritionally at-risk older patients following discharge from acute hospital to home: a systematic review and meta-analysis. Journal of human nutrition and dietetics. 2016;29.2:196-208.

35. Thompson, FE \& Byers T. Dietary assessment resource manual. Journal of Nutrition.1994; 2245S-2317S.

36. Wolfe RR. The role of dietary protein in optimizing muscle mass, function and health outcomes in older individuals. Br J Nutr. 2012;108::S88-93.

37. Morley JE, Argiles JM, Evans WJ et al. Nutritional recommendations for the management of sarcopenia. J Am Med Dir Assoc. 2010;11:391-396. 